IJLRES - International Journal on Language, Research and Education Studies

ISSN: 2580-6777 (p); 2580-6785 (e)

DOI: $10.30575 / 2017 /$ IJLRES-2018050804

Vol. 2, No. 2, 2018

Page: $195-207$

\title{
TRANSLATION TECHNIQUES AND QUALITY IN THE ENGLISH VERSION OF NGANTING MANUK TEXT
}

\author{
Muhizar Muchtar \\ University of North Sumatra, Indonesia \\ muhizarm@yahoo.com \\ Farida Repelita Waty Kembaren \\ State Islamic University of North Sumatra, Indonesia \\ faridauin@gmail.com
}

\begin{abstract}
The aims of this study are to identify translation techniques in the English version of nganting manuk text, to elaborate reasons of applying the most dominant translation technique in the English version of nganting manuk text, and to describe the translation quality of nganting manuk text in accuracy, acceptability, and readability aspects. This descriptive qualitative research is an embedded-case study and oriented to translation product. The data consist of words, phrases, clauses, and sentences in nganting manuk text, and the translation quality information from the key informants. The data are collected by document analysis, questionnaire, and analyzed by interactive data analysis technique. There are 10 translation techniques to translate nganting manuk text; borrowing, amplification, adaptation, literal, reduction, established equivalent, transposition, modulation, discursive creation, generalization, and the most dominant technique is borrowing influenced by the translator's foreignization perspective. The translation quality is good enough; accuracy (70.4\%), acceptability (63.4\%), and readability (66.1\%). One proposed theory is to use Cultural Information Philosophy (CPI) in the footnote to get the reader understanding the local wisdom of Karonese and the philosophy of nganting manuk text.
\end{abstract}

Keywords: Nganting manuk, translation technique, quality.

\section{INTRODUCTION}

The difficulty often experienced by a translator is translating cultural text because in translating cultural text, the translator is not only dealing with linguistics differences but also the cultural gaps of both languages. Therefore, translating cultural text gets special attention by translators because translators participate in preserving the local wisdom of the source text in the target text. Local wisdom of society can be utilized to improve the welfare and create peace in society that has been dreamt by people 
(Sibarani, 2012) ${ }^{1}$. Newmark (1988, p.94) considered cultural term as personal language that is different with universal words. Newmark gave some examples of cultural terms such as; 'monsoon', 'steppe', 'dacha', 'tangliatelle' which rise problems of translation. ${ }^{2}$

To translate cultural text, translator needs to use proper translation technique to produce accurate, acceptable, and high readability text. Moreover, translator also needs to understand the source and target language including the culture of both texts. This is due to the fact that translating cultural text will not only undermine the meaning of the source text, but also the damage the culture of the text. For example:

Table 1.1. The example of translating cultural text

\begin{tabular}{|l|l|}
\hline Source text & Target text \\
\hline $\begin{array}{l}\text { Kerna gantang tumba (unjuken) si man } \\
\text { alonken kalimbubu, bagenda: }\end{array}$ & Gantang Tumba (unjuken) received by \\
$\begin{array}{l}\text { Batang unjuken... Rp 1.200; } \\
\text { Kanam-lanam/teruh pinggan/ganti }\end{array}$ & Batanbubu is: \\
gigeh...Rp 60.000; & Lanam-lanam/teruh pinggan/ganti \\
Rudang-rudang....Rp 12.000; & gigeh...Rp 60.000; \\
Senina kuranan....Rp 3.000; & Rudang-rudang...Rp 12.000; \\
Ugapasa akapndu? & Senina kuranan....Rp 3.000; \\
& Then, what do you think? \\
\hline
\end{tabular}

Translators used borrowing technique to translate 'gantang tumba, unjuken, lanamlanam, rudang-rudang, and senina kuranan to maintain the authenticity of the cultural values of the source text. This is important to do, but well conveying message of the source text to be understood by target reader is also important. Because the word 'kalimbubu' is not given equivalent in the target text, target reader can't understand the meaning of 'kalimbubu', and it causes the message of the source text is not conveyed well.

Malinowski (1969) experienced difficulties in translating cultural text into English. ${ }^{3}$ When he used free translation technique, he found that the target reader could understand the message of the source text, but could not understand the cultural value of the source text. When he used literal translation technique, he found that target reader could understand social and cultural value of the text, but had difficulty to understand the message of the source text. In the end, he chose to equip the translation with

\footnotetext{
${ }^{1}$ R. Sibarani, Kearifan Lokal: Hakikat, peran, dan metode tradisi lisan, Asosiasi Tradisi Lisan, Jakarta Selatan, 2002.

${ }^{2}$ Peter Newmark, A Textbook of Translation, Prentice Hall, Great Britain, 1988.

${ }^{3}$ Malinowski, A Scientific Theory of Culture and Other Essays, Oxford University Press, New York, 1969.
} 
commentary as a bridge to bring the situation of the text. Since that time, he believed that a text cannot be understood without understanding the situational context of the text itself.

In accordance with the experience Malinowski had, Saleh (2006) argued that the cultural term cannot be translated because when translating the Classical Malay Chronicles - Hang Tuah into English, he found many cultural terms had no equivalent in Indonesia. ${ }^{4}$ For example, the term 'makan sirih' may not be translated into English as 'eating betel leaves' because it will be difficult for English readers to understand besides it will make a loss of cultural values contained in the word. Therefore, Saleh chose not to translate the terms related to culture, but it gives the explanation in the glossary.

Based on the opinion above, researcher concludes that the translation of cultural text should not only convey the message well, but also convey the cultural values well. Thus, the researcher saw that the study of analyzing cultural text translation is important and interesting. This is due to find the translation techniques used by translator in translating cultural text, the use of proper translation technique to translate cultural text, and also the factor contributing to the use of those techniques. Besides, as multicultural country, Indonesia has diverse culture that should be preserved. Researcher can help to preserve Indonesia culture with translation study by introducing the translation of nganting manuk text to national or international society. In this way, Indonesia's youth generation will be prouder and more confidence to the cultural heritage Indonesia has. Moreover, the translation errors found in nganting manuk text will make the local wisdom of Karonese culture unconveyed. By analyzing nganting manuk text translation the translation quality of nganting manuk text can be used by translator to improve the quality of nganting manuk text translation.

\section{LITERATURE REVIEW}

There are various cultural text in Indonesia, but nganting manuk text is chosen as the object of this study. Nganting manuk text is a text used in a traditional ritual called nganting manuk. This tradition is a meeting between the groom and bride family to discuss the amount of dowry will be received by bride family. This hereditary need to

${ }^{4}$ M. Salleh, Romance and Laughter in the Archipelago Essays on Classical and Contemporary Poetics of Malay World, University Sains Malaysia, Pulau Pinang, 2006. 
be maintained, preserved, and introduced to the world as one characteristics of traditional marriage in Karonese society as one of thousands tribes in Indonesia. Besides, it has not been found one study that focus on the English translation of nganting manuk text. This nganting manuk text uses Karonese language as the original language of Karonese society in daily life. Karonese society is one ethnic in Indonesia domiciled in various areas in North Sumatra (Prinst, 2012). 5

The text used in nganting manuk tradition is summarized in a book named Adat Karo by Darwan Prinst published in 2012. Then, the Karonese language text was translated into English by Bahagia Tarigan in 2013. The English version of nganting manuk text encouraged researcher to analyze the text in order to identify translation techniques used by translator in translating nganting manuk text, elaborating the factor contributing to the use of the most dominant technique in nganting manuk translation text, and to describe the quality of nganting manuk translation text.

\section{METHODOLOGY}

This study led to the translation product. Research about translation product can be done by comparing the source text with the target text. Translation unit of this study is at the level of words, phrases, clauses, and sentences in the nganting manuk text in Karonese and its translation in English. The data were analyzed to achieve the research objectives; to find the translation techniques used in nganting manuk text translation, to find the most dominant translation technique used in nganting manuk text translation, and to elaborate the factors contributing to the use of most dominant translation technique in nganting manuk text translation, and also to describe the translation quality of nganting manuk text translation.

This study uses descriptive qualitative approach with embedded cause study design. The strategy done by researchers of qualitative study is by considering themselves know only few things about what they want to study (Bogdan and Biklen, 1982). The descriptive qualitative approach was chosen because this study is focused on problems that exist at the time this study conducted (Nawawi, 1998). In addition, the text studied is qualitative data in the form of words, phrases, clauses, and sentences in nganting manuk text translation. Embedded case study was chosen because the data

${ }^{5}$ D. Prints, Adat Karo (3 ed.), Bina Media Perintis, Medan, 2012. 
source and the translation product analyzed were determined before the study started. Besides, the conclusion drawn is embedded (only applies to the research analyzed).

Qualitative research collect, analyze, and interpret data in the form of verbal description/words (Sumintono and Widhiarso, 2015). The data sources of qualitative study can be human, event, activity, place or premise, object, image, recording, as well as document and archive (Sutopo, 2002)6. The data source of this study is nganting manuk text in Karonese summarized by Darwan Prinst in a book entitled Adat Karo published by Bina Media Perintis 2012 on chapter 10 page 312-323 and its English translation by Bahagia Tarigan in 2016 published by CV. Mitra Medan, and the information of accuracy, acceptability, and readability by key informant. The data of this study are words, phrases, clauses, and sentences in nganting manuk text and its English translation. The data were classified and labeled in the form of data numbers. There were 110 data for this study, the research chose 71 significant data with cultural terms to be analyzed the translation techniques and the translation quality. The translation quality was analyzed by different informant in the aspect of accuracy, acceptability, and readability.

The method of collecting data was observation, document analysis, and questionnaire. The observation method is the observation of everyday life with five senses while document analysis was done by document reads and records. (Sutopo, 2006: 81) stated that content analysis technique which is a way to find a variety of things in accordance with the needs and goals of the research. In practice, this technique is done by reading the nganting manuk text and its translation as a whole to gain general description and identify the texts that have cultural terms. Then, the information of translation quality was collected from questionnaire in the form of translation quality instrument given to key informant. To see the quality of nganting manuk text translation, instrument was used. The instrument is translation quality instrument adapted from Nababan (2012). ${ }^{7}$ The instrument has been modified, and there were three instruments used to analyze the translation quality. The three instruments were given to translator practitioners to analyze the quality of nganting manuk text translation.

\footnotetext{
${ }^{6}$ H. B. Sutopo, Metodologi Penelitian Kualitatif, Dasar Teori dan Terapannya dalam Penelitian, Sebelas Maret University Press, Surakarta, 2002.

${ }^{7}$ M., Nababan, A Nuraeni, \& Sumardiono, Pengembangan Model Penilaian Kualitas Terjemahan, Kajian Linguistik dan Sastra, 2012, p. 39-57.
} 
Three kinds of instruments were used in this study; accuracy rating instrument, acceptability rating instrument, and readability rating instrument. Those instruments are statements provided to be chosen by key informant to see the translation quality of nganting manuk text translation. To assess the translation quality of nganting manuk text translation, the researcher adapt translation quality instrument proposed by Nababan (2012). The model of data analysis applied in this study is interactive model analysis by Miles and Huberman (2014) $)^{8}$ which is an interaction among the components with the process of data collection in the form of cycle. Data were analyzed by using interactive model of analysis Miles and Huberman performed interactively and runs continuously until the end and no longer obtained new data or information.

\section{FINDINGS AND DISCUSSION}

\section{Translation techniques used by translator}

Nganting manuk text has varied frequencies. The frequency of the most dominant techniques are as followed: Borrowing 70 times (95.6\%), amplification technique 54 times $(76.1 \%)$, adaptation 36 times (50.7\%), literal technique 28 times $(39.4 \%)$, reduction technique 26 times (36.6\%), established equivalent 20 times (28.2\%), transposition 15 times $(21.1 \%)$, discursive creation 14 times (19.7\%), modulation 14 times (19.7\%), and generalization 4 times $(5.63 \%)$.

The frequency of translation technique showed that the most dominant translation technique used is borrowing technique 70 times (95.6\%). Borrowing technique was applied most all of the data chosen. The result of translation techniques analysis in nganting manuk text translation also showed that some cultural terms borrowed directly from the source language were not given equivalent meaning in the target text. This can be seen from the use of borrowing technique 70 times (95.6\%) was not equal to the use of amplification techniques 54 times $(76.1 \%)$.

\section{Factors contributing to the use of borrowing and amplification techniques}

Factors triggers to the use of borrowing and amplification techniques in nganting manuk text translation are the frequency of borrowing and amplification technique. The

${ }^{8}$ M. B. Miles, A. M. Huberman, \& J. Saldana, Qualitative Data Analysis: A Methods Sourcebook (3 ed.), Sage, Arizona State University, 2014. 
use of borrowing technique introduces the cultural value of source text in the target text. Therefore, the frequency of cultural terms borrowed directly from the source language proves that the factors triggered to the use of those dominant techniques are translator perspective that is more faithful to the source text. Nganting manuk text translation oriented to the source text showed that the translator adheres to the ideology of foreignization.

Nganting manuk text translation oriented to source text has a goal to introduce a culture of Karonese tradition - Nganting manuk to target readers. The translator of nganting manuk text gave some explanations about the cultural terms borrowed directly from the source language in the footnotes (amplification technique). By applying borrowing and amplification technique, translator can introduce the cultural value of the source text in the target text.

The crucial role of translator in cultural exchange among nations made translator more careful in translating cultural text so that the cultural values can be conveyed well to target readers. The cultural terms can be raised by applying borrowing technique. Then, the meaning of those cultural terms can be given by applying amplification technique in footnotes.

Even so, to achieve the purpose of translating nganting manuk text which is to introduce one kind of Karonese culture, cultural information philosophy (CPI) also needs to be given in the target text. Based on this, one theoretical understanding is acquired that is by adding cultural philosophy information in amplification techniques (in the footnotes). By this way, the target readers should be able to understand both the message and also the cultural philosophy information of the source text, so the local wisdom of Karonese culture can be conveyed and understood by the target readers. The application of cultural philosophy information can be seen as followed:

Table 1.2. The application of cultural philosophy information

\begin{tabular}{|c|c|c|}
\hline No. & Source text & $\begin{array}{l}\text { Target text } \\
\text { (borrowing, amplification } \\
\text { cultural philosophy information) }\end{array}$ \\
\hline 21 & $\begin{array}{l}\text { E: "Sue ras arihta sanga maba belo } \\
\text { selambar maka sendah kita } \\
\text { nganting manuk. Bage gia, erkite- } \\
\text { kiteken keraben ndai kalimbubu } \\
\text { kami ras diri kalimbubunta } \\
\text { Sebayang enggo ngaloken pasu- } \\
\text { pasu. Emaka nungkun mendakami, }\end{array}$ & $\begin{array}{l}\text { E: Based on our meeting in maba belo } \\
\text { selambar, today we will have nganting } \\
\text { manuk meeting. Moreover, our } \\
\text { kalimbubu and kalimbubu Sebayang } \\
\text { has got marriage. Then, we are willing } \\
\text { to ask about whether we need to talk } \\
\text { about the former discussion. }\end{array}$ \\
\hline
\end{tabular}




\begin{tabular}{|l|l|l|}
\hline $\begin{array}{l}\text { uga nge nungkuni denga nge kami } \\
\text { entah lanai?" }\end{array}$ & \\
\hline
\end{tabular}

Note:

Maba belo selambar : a traditional proposal ceremony in Karonese society. The aim is to ask the willingness of the girl, parents, sembuyak, anak beru, kalimbubu, si ngalo bere-bere, and si ngalo perkempun about the proposal. (The groom's family will come to bride's family house by bringing (maba) belo (betel leafs) including with kapur [slacked lime], tembakau [tobacco], and pinang [betel nut] as a symbol of honor from the guess [groom's family] to the hosted [bride's family]. Tobacco reflects to interaction of groom's family with bride's family).

Nganting manuk: the continuation of maba belo selembar in which both families discuss about the amount of Gantang Tumba should be received by bride's family. (Groom's family will gather in bride's house by bringing (nganting) chicken (manuk) served in dinner before discussing wedding's dowry)

Kalimbubu: a community of clan [brothers] of our wives, our mothers, our fathers, our sons' wives, and wives of our brothers.(The group who gives a girl to one clan. They're well known as dibata ni idah [the visible God] because they are really respected in Karonese tradition).

In the text above, it can be seen that the cultural terms; maba belo selambar, nganting manuk, and kalimbubu were borrowed directly from the source language. By applying borrowing technique, cultural terms can be introduced and appeared in the target text. Then, amplification technique was used by explaining the meaning of those cultural terms in the footnotes. Maba belo selambar was explained in the footnotes as a traditional proposal ceremony in Karonese society. The aim is to ask the willingness of the girl, parent, sembuyak, anak beru, kalimbubu, si ngalo bere-bere and singalo perkempun about the engagement proposal. Then, nganting manuk was explained to be the continuation of maba belo selembar in which both families discuss about the amount of Gantang Tumba should be received by bride's family. Meanwhile, kalimbubu was explained to be a community of clan [brothers] of our wives, our mothers, our fathers, our sons' wives, and wives of our brothers.

Nevertheless, up to this point, the target reader can not understand the cultural value and the local wisdom of Karonese culture which is why Karonese society called the engagement as maba belo selambar that literally means bring betel leaves, why the discussion of dowry called as nganting manuk that literally means bring a chicken, and how the actual value of Karonese culture behind the term - kalimbubu in Karonse 
society. Therefore, it is necessary to give cultural philosophy information in the footnotes to convey the cultural philosophy of the terms to target readers. In the example above, the cultural philosophy information was gained from traditional leaders in Karo society who knows exactly the philosophy meaning behind those cultural words.

The cultural philosophy information given for maba belo selambar is The groom's family will come to bride's family house by bringing (maba) belo (betel leafs) including with kapur [slacked lime], tembakau [tobacco], and pinang [betel nut] as a symbol of honor from the guess [groom's family] to the hosted [bride's family]. Tobacco reflects to interaction of groom's family with bride's family). By giving this cultural philosophy information, the target reader can understand that the proposal ceremony of Karonese society is called maba belo selambar (bring a piece of betel leave) because giving betel leave including with slacked lime, tobacco, and betel nut is taken as a symbol of honor from the groom family to the bride family. By giving this cultural philosophy information, the target reader can understand the local wisdom of Karonese culture which is the guest glorifies the hosts by bringing something to encourage interaction between the both families. Generally, the host is the one who glorifies the guest. This Karonese local wisdom can be introduced to national and international society by cultural exchange of every nation.

Next, the cultural philosophy information for nganting manuk is Groom's family will gather in bride's house by bringing (nganting) chicken (manuk) served in dinner [as a symbol of familiarity] before discussing wedding's dowry. By giving this cultural philosophy information, the target readers will understand the local wisdom of Karonese society which is called as nganting manuk because the main menu brought by the groom family is chicken which is a symbol of tighten the relationship between both families. Besides, the target readers will also understand the local wisdom of Karonese society by understanding that Karonese ethnic starts a meeting by having dinner together with the side dish provided. The goal is to strengthen the sense of togetherness between both families.

Then, the cultural philosophy information for kalimbubu is The group who gives a girl to one clan. They're well known as dibata ni idah [the visible God] because they are really respected in Karonese tradition. By giving this cultural philosophy information, the target readers will understand that kalimbubu's role as the group who gives the bride is really respected in Karonese society. By giving this cultural philosophy information in the footnotes, the target readers not only recognize and understand the meaning of cultural 
terms in the target text, but also understand the cultural philosophy of the unique cultural terms.

\section{Nganting manuk translation quality}

The translation quality of nganting manuk text in the aspects of accuracy, acceptability, and readability were analyzed by different key informant. The accuracy was analyzed by translation practitioner who masters Karonese and English language, the acceptability was analyzed by English lecturer who master Karonese and English, and the readability was analyzed by student of English Education Department. The highest score for each aspect is 3, and the lowest score is 2 . Of the 71 data analyzed, it was obtained that the percentage of accuracy is 70.4\% (50 data), acceptability $63.4 \%$ (43 data), and readability $66.1 \%$ (47 data). The factor contributing to the result of translation quality of nganting manuk text translation is because there were some cultural terms that have no equivalence in the target text, and they caused the target readers confused and influenced the translation quality of nganting manuk text. Based on the result, it can be concluded that the quality of nganting manuk text translation is pretty good, but it still needs an improvement. Generally, the quality of nganting manuk text translation can be seen in the figure below:

Figure 1. The translation quality of nganting manuk text

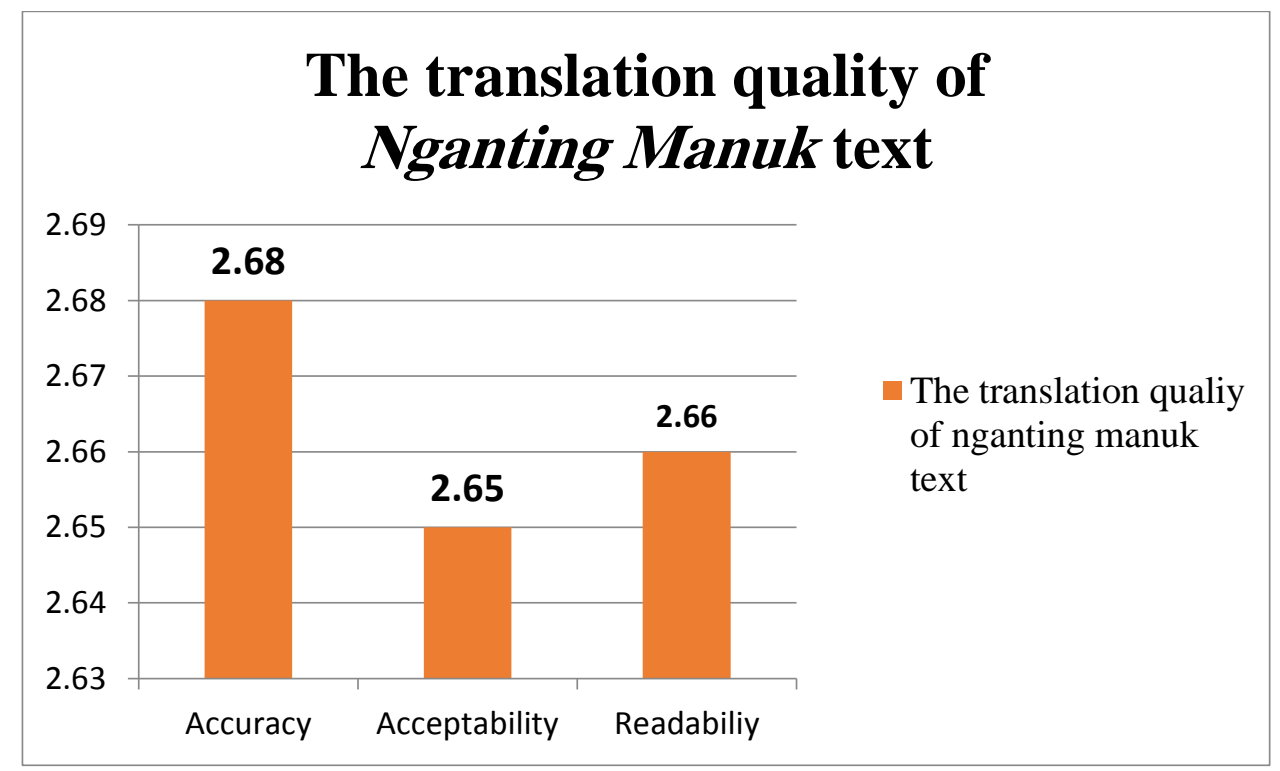




\section{CONCLUSION}

Based on the objectives of this study, the data of this study were analyzed so that it can be concluded as follow:

1) Ten types of translation techniques applied in nganting manuk text translation were discovered. Those techniques are adaptation, amplification, borrowing, discursive creation, established equivalence, generalization, literal translation, modulation, and reduction. The most dominant translation technique used is borrowing technique 70 times (95.6\%). Some cultural terms borrowed directly from the source language have no equivalence in the target text. It can be seen from the frequency of borrowing technique (70 times [95.6\%]) that is not equal to the frequency of amplification technique (54 times [76.1\%]).

2) The factor contributing to the high frequency used of borrowing and amplification technique is foreignization perspective the translator has. The application of borrowing and amplification technique in nganting manuk text seeks to produce a faithful translation which emphasized the source text instead of the target text. It is useful to maintain the cultural authenticity of the source text instead of using equivalents that are closer to the culture of the target language. The cultural terms can be introduced by applying borrowing technique. The meaning of those cultural terms also can be given by applying amplification technique in the footnotes. However, to achieve the purpose of translating nganting manuk text that is to introduce one kind of Karonese culture, then cultural philosophy information should also be given in the target text to make the target reader can recognize the local wisdom of Karonese society. By this point, one development of theoretical understanding was acquired which is by adding the cultural philosophy information (CPI) in amplification technique in the footnotes. In this way, the target reader should be able to recognize and understand the cultural philosophy information and the local wisdom of Karonese society in nganting manuk text translation.

3) It was found that the quality of nganting manuk text translation was pretty good, but it still needs to be improved. The percentage of nganting manuk text translation was accuracy 70.4\% (50 data), acceptability 63.4\% (43 data), and readability $66.1 \%$ (47 data). The factor contributing to translation quality of nganting manuk text was because there were some cultural terms that have no 
equivalents in the target text. The cultural terms that have no equivalent confused the target readers and influenced the quality of nganting manuk text translation.

\section{BIBILIOGRAPHY}

Arikunto, S. (2010). Prosedur Penelitian: suatu pendekatan dan praktik (revisi ed.). Jakarta: Rineka Cipta.

Chin, W. Z. T. (2015). The role of translation in cross-cultural knowledge transfer within a MNE's business networks. Chinese Management Studies, 9(4), 589-610. doi: 10.1108/CMS-06-2015-0114

Drugan, J. (2013). Quality in Professional Translation: Assessment and Improvement. India: Bloomsbury.

Hoed, B. H. (2006). Penerjemahan dan Kebudayaan. Jakarta: PT Dunia Pustaka Jaya.

Machali, R. (2009). Pedoman Bagi Penerjemah: Panduan Lengkap bagi Anda yang Ingin Menjadi Penerjemah Professional. Bandung: Penerbit Kaifa PT Mizan Pustaka.

Malinowski. (1969). A Scientific Theory of Culture and Other Essays. New York: Oxford University Press.

Miles, M. B., Huberman, A. M., \& Saldana, J. (2014). Qualitative Data Analysis: A Methods Sourcebook (3 ed.). Arizona State University: Sage.

Mohd., A., \& Hassan, A. (2008). Teori dan Teknik Terjemahan (Khas ed.). Kuala Lumpur: Institut Terjemahan Negara Malaysia Berhad (ITNMB).

Molina, L., \& Albir, A. H. (2002). Translation Techniques Revisited: A Dynamic and Functionalist Approach. Meta, XLVII(4), 498-512.

Nababan, M., Nuraeni, A., \& Sumardiono. (2012). Pengembangan Model Penilaian Kualitas Terjemahan. Kajian Linguistik dan Sastra, 24(1), 39-57.

Newmark, P. (1988). A Textbook of Translation. Great Britain: Prentice Hall.

Newmark, P. (1991). About Translation. Great Britain: Multilingual Matters Ltd.

Prints, D. (2012). Adat Karo (3 ed.). Medan: Bina Media Perintis.

Robinson, D. (2005). Becoming a Translator (S. T. Work, Trans. M. W. \& Hananto Eds.). Yogyakarta: Pustaka Pelajar.

Salleh, M. (2006). Romance and Laughter in the Archipelago Essays on Classical and Contemporary Poetics of Malay World. Pulau Pinang: University Sains Malaysia.

Seong, G. S. (2012). Bahasa Cina Bahasa Melayu Kebolehterjemahan Budaya. Malaysia: Penerbit University Sains Malaysia. 

DOI: 10.30575/2017/IJLRES-2018050804

Sibarani, R. (2012). Kearifan Lokal: Hakikat, peran, dan metode tradisi lisan. Jakarta Selatan: Asosiasi Tradisi Lisan.

Sofyan, R. (2013). From Process to Product in Translation Studies. Paper presented at the The 14th International Conference on Translation 7th Asian Translators' Forum, Malaysia.

Sutopo, H. B. (2002). Metodologi Penelitian Kualitatif, Dasar Teori dan Terapannya dalam Penelitian Surakarta: Sebelas Maret University Press.

Venuti, L. (1995). The Translator's Invisibility. A History of Translation. London: Routledge.

Xian, H. (2008). Lost in translation? Language, culture and roles of translator in crosscultural management research. Qualitative Research in Organizations and Management: An International Journal, 3(3), 231-245. doi: 10.1108/17465640810920304 